of well-intentioned debtor governments for example? That is the sort of stratagem that the IMF should be exploring. If it cannot, there may be no choice but an international conference of debtors and creditors at which they hammer out a settlement in concert. The present mess cannot be allowed to continue.

\section{Amis and MacGregor}

British universities cannot expand a second time without qualitative change.

WHEN the first great expansion of British higher education was set in train by the Robbins Report in 1963, public argument in Britain was quickly polarized around $\mathrm{Mr}$ Kingsley Amis's complaint that "more means worse". Mr John MacGregor, the British Secretary of State for Education and Science, has evoked none of that trouble by his casual announcement that his government now hopes that the participation rate in higher education (the percentage of school leavers following degree courses either then or later) will increase to 23 per cent by the end of the century (see Nature 341, 371; 1989). But MacGregor will not be able to forget Amis's complaint for long. Already, the vice-chancellors (otherwise rectors or presidents, according to geography) of British universities have made it plain that there will be a reduction of the quality of higher education if the government does not meet the cost of teaching extra students. That is inescapable, but only half the problem.

The error - some would say the folly - of the then government's response to the Robbins report was its assumption that a twofold expansion could be accomplished without a qualitatitve change in teaching methods. One result was the creation of a new crop of universities in the image of pre-existing universities. Only now have the authorities concluded that many British universities are too small to sustain substantial research programmes - or even to be full universities, teaching philosophy as well as physics. (Some have dropped both.) Both the universities and the British government should be careful to avoid that mistake a second time.

The dilemma for both is worsened by the otherwise welcome prospect that secondary education will in future be less specialized. Students at secondary schools will no longer be expected to win places in specialized courses at universities by virtually demonstrating that they can already do what may afterwards be required of them. But universities have traditionally complained that they cannot take young people through the traditional British specialized degree course in three years if students are a whit less well-prepared than at present. The best solution must surely be that some universities should become fouryear universities. The question then is merely whether the government will meet the extra cost. On the face of things, it has no choice.

There are intellectual as well as administrative prob- lems for the universities to tackle. The truth is that the extra 10 per cent of young people McGregor is urging towards higher education will have different needs. Britain's higher education is already notorious for production engineers who do not understand economics, historians who are computer-illiterate and scientists who know only English, and that sometimes imperfectly. What will the British system of higher education, jealous of its independence and traditions, do to accommodate the different needs of its new students? Especially now that 1992 is not far away?

\section{Benefactor needed}

There needs to be an imaginative response to a Soviet offer to create an international centre on Lake Baikal.

Not so long ago, it was common to hear complaints that the Soviet government was allowing the ruin of one of the world's most remarkable natural monuments, the huge inland sea against the border with Mongolia known as Lake Baikal. It is true, of course, that for a long time bureaucratic impediments exaggerated the natural difficulties of reaching this remote place, so that pollution of the world's largest natural reservoir of fresh water could not be independently monitored and assessed. The good news is that the alarms of the past few decades have been without foundation; Lake Baikal remains more or less in its pristine state. The remarkable news is that the Soviet authorities are deadly serious in their willingness to throw Lake Baikal open to international research (see page 481). Even if the rest of the world does not quickly seize the opportunity, there is already enough collaborative work under way to make a respectable research programme.

But it must be hoped that matters will not rest there. The plans put forward are for a research centre sited on the lake whose programme will be determined by researchers, and not by other interests. The objective is not simply to learn more about Lake Baikal, but to tell whether this distinctive body of water holds the key to other contemporary puzzles, the record of climatic change and the pace of tectonic or even evolutionary change, for example. Practical benefits, especially in the development of monitoring techniques, are an extra.

The difficulty, as always, is the accomplishment of this objective. There will be a need, in the next few years, for something like $\$ 20$ million in hard currency to establish the infrastructure of a working research centre. It would be preferable if governments were not directly involved, although they are the most obvious sources of funds on such a scale. (Russians, accustomed to print money when they need more of it, do not appreciate the struggles required in the West to raise sums of this kind, but $\mathrm{Mr}$ Gorbachev's promised budget reforms may change all that.) Could this be a case where one of the larger foundations will recognize that the time has come to back an imaginative scheme imaginatively? 